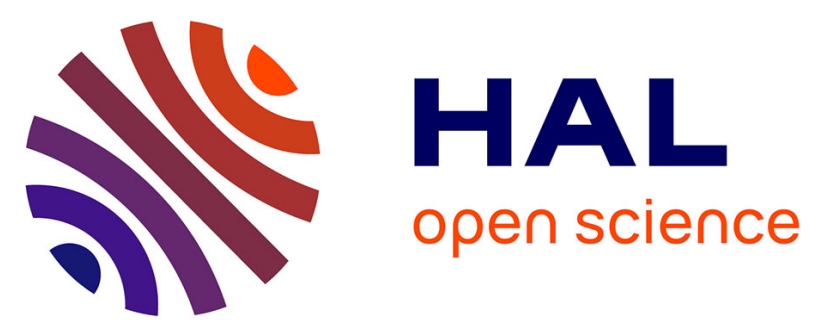

\title{
Seasonal variability of the elemental composition of atmospheric aerosol particles over the northwestern Mediterranean
}

\author{
Gilles Bergametti, Alain-Louis Dutot, Patrick Buat-Menard, Rémi Losno, \\ Emmanouela Remoudaki
}

\section{To cite this version:}

Gilles Bergametti, Alain-Louis Dutot, Patrick Buat-Menard, Rémi Losno, Emmanouela Remoudaki. Seasonal variability of the elemental composition of atmospheric aerosol particles over the northwestern Mediterranean. Tellus B - Chemical and Physical Meteorology, 1989. hal-02328304

\section{HAL Id: hal-02328304 https://hal.science/hal-02328304}

Submitted on 23 Oct 2019

HAL is a multi-disciplinary open access archive for the deposit and dissemination of scientific research documents, whether they are published or not. The documents may come from teaching and research institutions in France or abroad, or from public or private research centers.
L'archive ouverte pluridisciplinaire HAL, est destinée au dépôt et à la diffusion de documents scientifiques de niveau recherche, publiés ou non, émanant des établissements d'enseignement et de recherche français ou étrangers, des laboratoires publics ou privés. 


\title{
Seasonal variability of the elemental composition of atmospheric aerosol particles over the northwestern Mediterranean
}

\author{
By GILLES BERGAMETTI*, ALAIN-LOUIS DUTOT†, PATRICK BUAT-MÉNARD \\ RÉMI LOSNO* and EMMANOUELA REMOUDAKI*, ${ }^{*}$ Laboratoire de Physico-Chimie de \\ l'Atmosphère, UA CNRS 717, Université Paris 7, 2 place Jussieu, F-75251 Paris Cedex 05, France; \\ $\dagger$ Laboratoire de Physico-Chimie de l'Environnement, UA CNRS 717, Université Paris 12, Avenue du \\ Général De Gaulle, F-94010 Créteil Cedex, France; $\ddagger$ Centre des Faibles Radioactivités, Laboratoire Mixte \\ CNRS-CEA, BP 1, F-91190 Gif-sur-Yvette, France
}

(Manuscript received 29 December 1987; in final form 20 July 1988)

\begin{abstract}
Beginning in 1985, a continuous aerosol sampling program has been undertaken at a coastal location in northwestern Corsica. This site is $300 \mathrm{~m}$ above sea-level and at least $20 \mathrm{~km}$ from local pollution sources. It is exposed during $80 \%$ or more of the time to maritime air masses which have travelled over the western Mediterranean from southern, western and northern directions. Daily 24-h aerosol samples were collected on $0.4 \mu \mathrm{m}$ pore size nuclepore filters from a $10 \mathrm{~m}$ high tower and analysed for $\mathrm{Al}, \mathrm{Si}, \mathrm{P}, \mathrm{S}, \mathrm{K}, \mathrm{Ca}, \mathrm{Ti}, \mathrm{Mn}, \mathrm{Fe}$ and $\mathrm{Zn}$ by X-ray fluorescence, and for $\mathrm{Na}, \mathrm{Cu}$ and $\mathrm{Pb}$ by flameless atomic absorption. The data obtained up to now, from April 1985 to April 1986, show that the temporal variability of the concentrations displays 2 distinctive patterns. First, a seasonal pattern is observed for the elements of continental origin, either natural (e.g., $\mathrm{Al}, \mathrm{Si}$ ) or anthropogenic (e.g., $\mathrm{S}, \mathrm{Pb}$ ). This pattern is inversely related to the frequency and amount of rainfall such that the highest concentrations are observed between May and October. Estimates based on these data indicate an average time of 2 days to reload that atmospheric environment with aerosol particles from continental sources. This seasonal pattern is not observed for locally produced sea-salt aerosol particles (index $\mathrm{Na}$ ), whose concentration is related to local wind speed. Elements associated with mineral aerosol particles exhibit sporadic but intense concentration peaks that are superimposed on this general pattern. 20 of these events were recorded for the sampling period considered with their frequency being maximal in spring and summer. 3-D air-mass trajectories show that all these events are associated with transport of soil dust from Africa.
\end{abstract}

\section{Introduction}

There is strong evidence that the atmospheric transport of trace-elements from anthropogenic and natural land-sources to the Mediterranean atmosphere plays a significant role in the geochemistry of Mediterranean sea-water (Arnold et al., 1982; GESAMP, 1985). The assessment of such an influence requires a quantitative knowledge of atmospheric concentrations and fluxes over this marine environment. However, such an assessment is difficult because of the strong vari- ability of atmospheric elemental concentrations. Previous works (Arnold et al., 1982; Chester et al., 1984; Dulac et al., 1987) have shown that the atmospheric trace metals concentrations are highly variable on a daily time scale over the northwestern Mediterranean. This variability can be due to changes in continental source strengths, airflow and precipitation patterns. These previous studies suggested that a continuous sampling strategy is needed to assess the inputs of trace-elements to the western Mediterranean marine environment on a yearly time scale. Such 
an approach has been conducted at a coastal site in Corsica Island since February 1985 (Bergametti, 1987). We present here daily atmospheric concentration data for some elements which are indicators of the major aerosol sources (soil erosion: $\mathrm{Al}, \mathrm{Si}$; pollution: $\mathrm{S}, \mathrm{Pb}$; sea-salt: $\mathrm{Na}$ ). The factors influencing the variability of their concentrations both at the daily and seasonal time scale are discussed.

\section{Material and methods}

\subsection{Sampling}

Atmospheric samples were collected at Capo Cavallo $\left(42^{\circ} 31^{\prime} \mathrm{N}, 8^{\circ} 40^{\prime} \mathrm{E}\right)$ on the northwestern coast of the Corsica Island. This site is located $300 \mathrm{~m}$ above sea-level and about $700 \mathrm{~m}$ distant from the shore line. It is exposed $80 \%$ of the time to marine air-mass coming to southwest to northeast. Moreover, the closest local pollution sources originating from the city of Calvi are distant from $20 \mathrm{~km}$. The aerosol samples were collected at the top of a $10 \mathrm{~m}$-high meteorological tower. Bulk filtration samples were performed on $0.4 \mu \mathrm{m}$ porosity nuclepore filters (diameter: $32 \mathrm{~mm}$ ). Sampling duration was $24 \mathrm{~h}$ with a nominal airflow of $1 \mathrm{~m}^{3} \mathrm{~h}^{-1}$. Using these sampling procedures, collection efficiency was found to be similar to that obtained with high-volume Whatman 41 air filter samples. Blank filters were subjected to all the manipulations made on the filters, except air filtration.

\subsection{Analytical methods}

For all samples, the concentrations of $\mathrm{Al}, \mathrm{Si}, \mathrm{P}$, $\mathrm{S}, \mathrm{K}, \mathrm{Ca}, \mathrm{Ti}, \mathrm{Mn}, \mathrm{Fe}, \mathrm{Zn}$ have been determined by wavelength dispersive $\mathrm{X}$-ray fluorescence spectrometry (Compagnie Générale de Radiologie 10), according to the method described by Elichegaray et al., 1981. The sample is placed in an irradiation chamber and the excitation is produced by an X-ray tube with a $\mathrm{Cr}$ (for $\mathrm{Al}, \mathrm{Si}$, $\mathrm{P}, \mathrm{S}, \mathrm{K}, \mathrm{Ca}, \mathrm{Ti}$ ) or $\mathrm{W}$ (for $\mathrm{Mn}, \mathrm{Fe}, \mathrm{Zn}$ ) target. The intensity of the $\mathrm{K}_{x} \mathrm{X}$-ray of each element is counted at least twice during 50 to $70 \mathrm{~s}$ on a proportional gaseous flux detector (for $\mathrm{Al}, \mathrm{Si}, \mathrm{P}$, $\mathrm{S}, \mathrm{K}, \mathrm{Ca}, \mathrm{Ti}, \mathrm{Mn}, \mathrm{Fe}$ ) or a scintillation detector (for $\mathrm{Zn}$ ). Total countings were corrected for the contribution of blank filters. The absence of significant matrix effects was checked by using three standards (Losno et al., 1987). The mean statistical errors taking into account the contribution of blank and uncertainties of the calibration curves are generally less than $10 \%$.

Following X-ray fluorescence analysis, flameless atomic absorption spectroscopy was performed to determine $\mathrm{Na}, \mathrm{Cu}$ and $\mathrm{Pb}$ concentrations. The sample is placed for about one week in a teflon bomb with $4 \mathrm{ml}$ of $\mathrm{HNO}_{3}$ Prolabo Normatom and $1 \mathrm{ml}$ of $\mathrm{HClO}_{4}$ Prolabo Normatom at a temperature of $60^{\circ} \mathrm{C}$. The liquid residue (about $1 \mathrm{ml}$ ) is then adjusted to $5 \mathrm{ml}$ with Milli-Q water. Working standards were prepared in a similar solution to allow matrix matching with the samples. The analyses were performed by using a Perkin-Elmer model 400 unit with HGA 500 graphite furnace. Mean relative errors have been estimated to $8 \%$ for $\mathrm{Cu}, 10 \%$ for lead and $12 \%$ for sodium.

\subsection{Meteorological data and air-mass trajectories}

Capo Cavallo is a station of the French meteorological network and all the basic meteorological parameters (wind velocity and direction, amounts of local precipitation, .... etc.) were generally recorded with a 3-or 6-h step.

Moreover, for each sample, 3-dimensional backward air-mass trajectories were computed to assess the transport of aerosol particles from their source regions by the Service des Etudes Spéciales, Météorologie Nationale, Paris. The air-mass trajectories were calculated over a period of 4 days, arriving at the 925 and $700 \mathrm{hPa}$ barometric levels, at the mid-time of each sampling period. They have been computed from the analytical wind field of the European Center for Medium Range Weather Forecast of Reading, England (Lorenc et al., 1977). The calculation of the altitude of air transport is based on an approximation of the vertical component of the wind (Martin et al., 1987).

\section{Results and discussion}

\subsection{Daily variations}

The daily variations of concentrations between 6 April 1985 and 23 April 1986 for $\mathrm{Si}, \mathrm{Al}, \mathrm{Pb}$ and $\mathrm{S}$ are presented in Figs. la-d. Bulk data can be found in Bergametti (1987). The geometric mean yearly concentrations of all the elements are 
Table 1. Yearly geometric mean and standard deviation of elemental concentrations $\left(\mathrm{ng} \mathrm{m}^{-3}\right)$ for the whole sampling period (374 samples)

\begin{tabular}{llcl}
\hline & $\begin{array}{l}\text { No. } \\
\text { significant } \\
\text { steps }\end{array}$ & $\begin{array}{l}\text { Geometric } \\
\text { mean }\end{array}$ & $\begin{array}{l}\text { Standard } \\
\text { deviation }\end{array}$ \\
\hline $\mathrm{Na}$ & 330 & 1000 & 2.76 \\
$\mathrm{Al}$ & 360 & 168 & 3.31 \\
$\mathrm{Si}$ & 374 & 427 & 3.41 \\
$\mathrm{P}$ & 360 & 10.2 & 2.14 \\
$\mathrm{~S}$ & 373 & 1672 & 1.97 \\
$\mathrm{~K}$ & 372 & 221 & 1.90 \\
$\mathrm{Ca}$ & 372 & 254 & 2.28 \\
$\mathrm{Ti}$ & 371 & 12.4 & 3.25 \\
$\mathrm{Mn}$ & 314 & 5.3 & 2.11 \\
$\mathrm{Fe}$ & 372 & 144 & 3.00 \\
$\mathrm{Cu}$ & 321 & 2.1 & 2.71 \\
$\mathrm{Zn}$ & 293 & 19.1 & 2.16 \\
$\mathrm{~Pb}$ & 329 & 15.9 & 2.34 \\
\hline
\end{tabular}

given in Table 1. The large standard deviations of the geometric mean suggest a significant variability of atmospheric concentrations. As shown by Figs. 1a-d, a high variability of atmospheric concentrations is observed on time scales of the order of one day: for example, the $\mathrm{Si}$ and $\mathrm{Al}$ concentrations change by a factor 200 in less than 48 hours, between 28 and 30 December 1985 .

Such strong variations for these two elements appear episodically through along the sampling period: high concentration episodes are more frequently oberved during summer and spring, more occasionally in fall and winter. On the other hand, low concentration episodes are frequently observed during fall and winter, more occasionally during summer. The air-mass trajectories (Fig. 2) indicate that all these high dust events were associated with transports from the arid or semi-arid African regions and corresponded to Saharan dusts inputs (Bergametti, 1987). 20 Saharan dusts events were observed during the sampling period (about 1 year).

Such high concentration levels do not appear on the figures $1 \mathrm{c}$ and $1 \mathrm{~d}$ which illustrate the daily variation of lead and sulfur. These elements result principally in the Mediterranean atmosphere of anthropogenic emissions by opposite to $\mathrm{Al}$ and $\mathrm{Si}$ which are predominantly of crustal origin (BuatMénard, 1986).
On the opposite, low concentration values are observed the same days for these four elements. Taking into account the different source-types and source-regions of these elements in the Mediterranean atmosphere, respectively the soil erosion and the human activities, this similar behaviour may not result only from changes in air-flow patterns. Precipitation data (Figs. 1a-d) indicate that the lowest concentration episodes correspond to sampling periods when the atmosphere was locally washed by rain. It can therefore be suggested that precipitation scavenging can explain the considerable decrease in concentrations which we observe simultaneously for $\mathrm{Al}, \mathrm{Si}, \mathrm{S}$ and $\mathrm{Pb}$. For example, the largest decrease in $\mathrm{Si}$ and $\mathrm{Al}$ concentrations (by a factor of 200) observed from 28-30 December 1985 corresponds to a Saharan dust event followed by local precipitations. For this period, air-mass trajectories indicate no change in airflow pattern.

\subsection{Seasonal pattern}

The data presented in Figs. la-d suggested also that these intense, short-term variations of atmospheric concentrations are superimposed on a seasonal pattern. Such a pattern is more clearly evident in Figs. 3a, b where are reported the monthly geometric mean of atmospheric concentrations. 2 well-defined periods during the year can be distinguished: (a) the Mediterranean "summer" (May-October) during which geometric mean concentrations of $\mathrm{Si}$ and $\mathrm{S}$ are respectively $1100 \mathrm{ng} \mathrm{m}^{-3}$ and $2660 \mathrm{ng} \mathrm{m}^{-3}$; (b) the rest of the year, between October and April, is characterized by lower mean concentrations (Si: $237 \mathrm{ng} \mathrm{m}^{-3}$ and $\mathrm{S}: 1360 \mathrm{ng} \mathrm{m}^{-3}$ ).

Two factors can explain these different seasonal changes in atmospheric concentrations: (1) a seasonal change in continental source strengths and/or airflow patterns and/or (2) a different removal rate for atmospheric particles between these two periods.

The first factor can be ruled out for the following reasons: a 10-year climatological study of airflows (1975-1984) in the northwestern Mediterranean region by Miller et al. (1987) indicates little or no seasonal variations of the frequency of airflow patterns at the $850 \mathrm{hPa}$ barometric level. We checked that this was also the case for the sampling period considered here. 

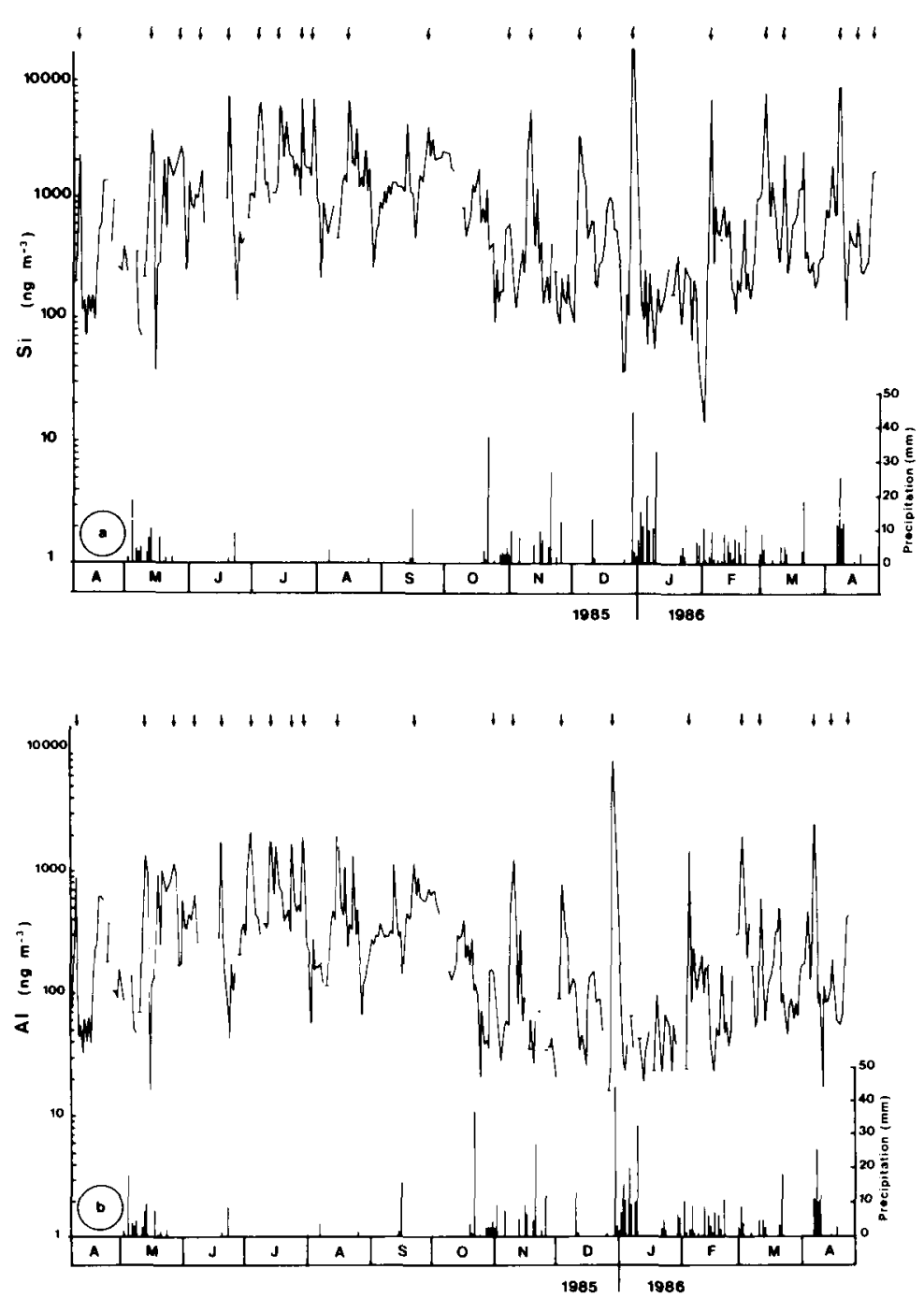

Fig. 1. Daily atmospheric concentrations (in nanograms per cubic meter) at Capo Cavallo (western Mediterranean $\mathrm{Sea}$; (a) $\mathrm{Si}$; (b) $\mathrm{Al}$; (c) $\mathrm{Pb}$; (d) $\mathrm{S}$. The arrows indicate southern airflows identified by air mass trajectories. The daily amount of precipitation is reported at the bottom of the figure.

Moreover, the similar behaviour oberved for elements emitted by different land-based sources suggests that the temporal variations of the source strengths are probably a factor of minor importance.

These observed seasonal changes seem to be better related to the local precipitation rate: indeed, the low concentration season corresponds to the rainy period in the western Mediterranean while the high concentration period occurs during the dry season (Fig. 3c).

Although our data set concerns only a one-year period, these observations strongly suggest the existence of a seasonal cycle of the atmospheric aerosol concentrations in the Mediterranean region: indeed, the precipitation patterns, which seem to be the major factor responsible for seasonal changes in aerosols concentrations, 

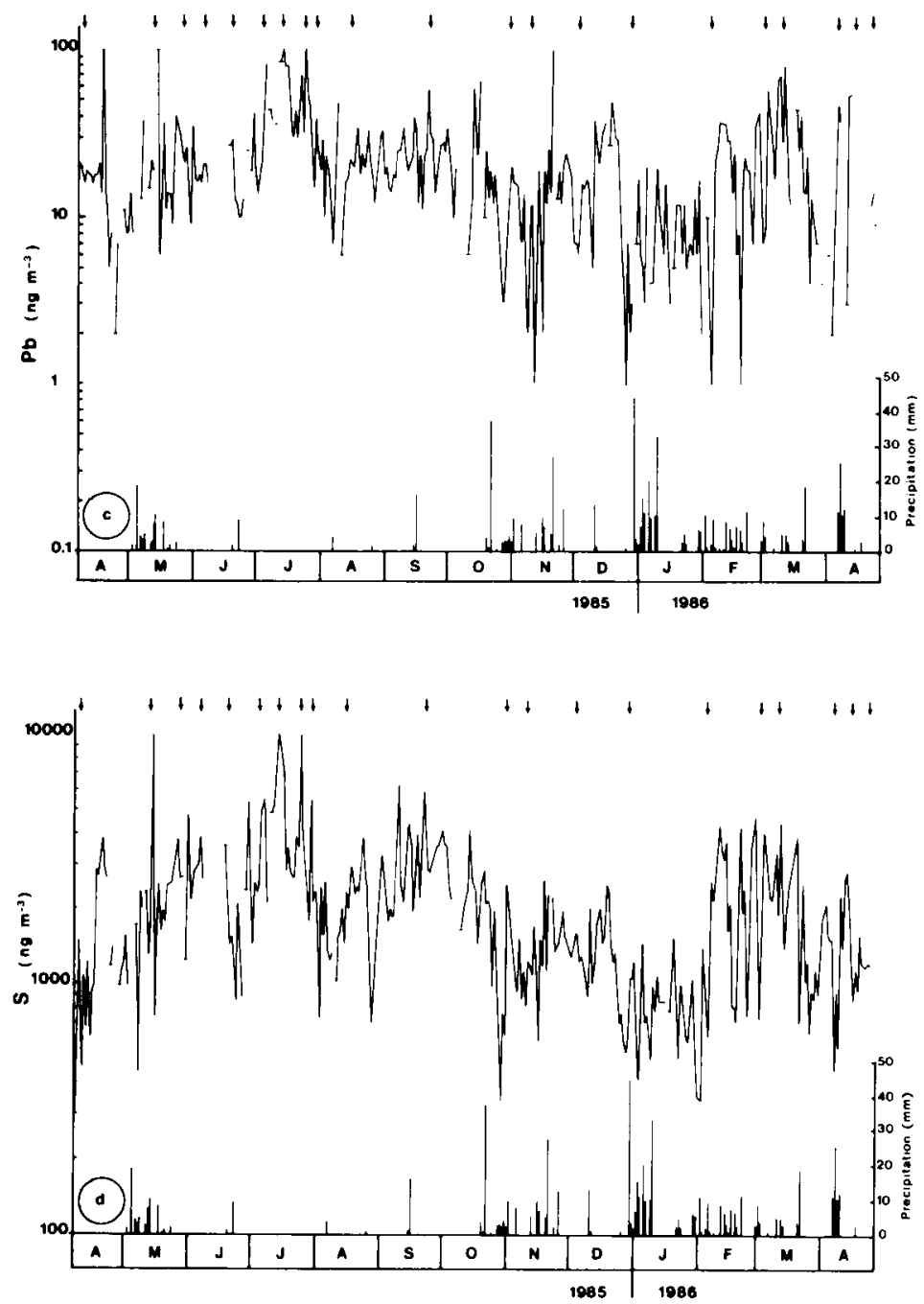

Fig. I (continued).

are characterized themselves by a well-known seasonal cycle in the western Mediterranean.

Fig. 4 illustrates that this seasonal cycle is observed for all the elements derived from landbased sources: crustal origin ( $\mathrm{Al}, \mathrm{Si}, \mathrm{Ti}, \mathrm{Fe})$, anthropogenic origin $(\mathrm{S}, \mathrm{Cu}, \mathrm{Zn}, \mathrm{Pb})$ and mixed origin (Mn, P, Ca, K) (Bergametti, 1987). This seasonality does not appear to be controlled by the size of aerosol particles since these elements are present in different particle size classes-fine fraction for sulfur and lead, coarse fraction for aluminium and silicon (Dulac et al., 1987; Bergametti, 1987).

In contrast, $\mathrm{Na}$ exhibits a different behaviour, with no difference of the mean geometric concentrations between the two periods.

Since $\mathrm{Na}$ is primarily associated with large seasalt particles, its source is likely to be mostly

Tellus 41 B (1989), 3 


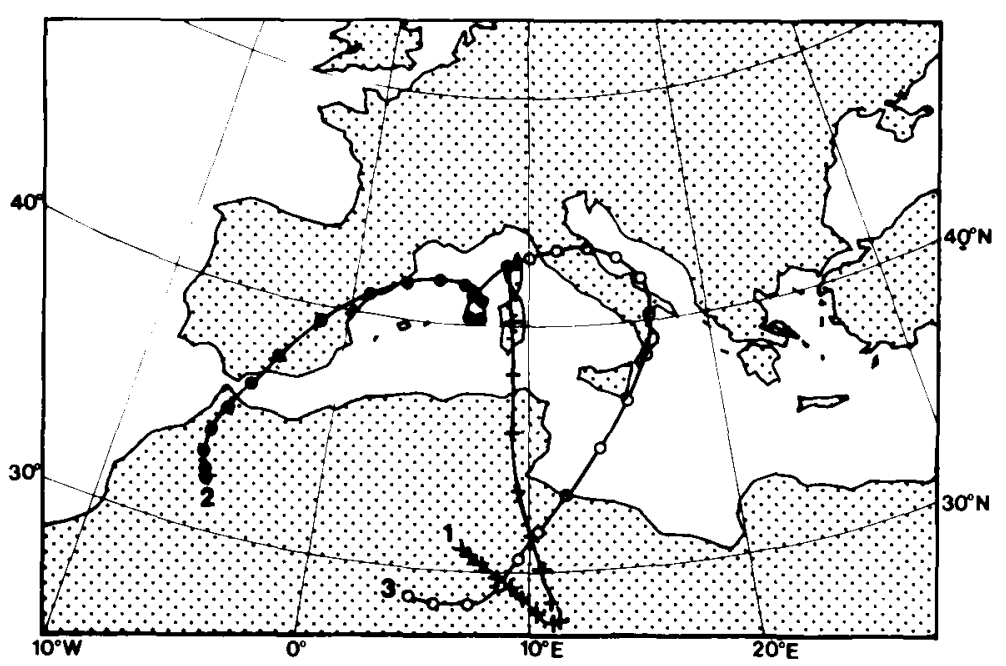

Fig. 2. Examples of backward air-mass trajectories coming from north Africa and ending at the $700 \mathrm{hPa}$ barometric level. These air-mass trajectories arrives on: (1) 1 March 1986; (2) 16 July 1985 ; (3) 22 September 1985.

local. This local character can be clearly shown for our data set. Indeed, Fig. 5 shows the classical relation between $\mathrm{Na}$ concentrations and local wind speed as previously observed by Lovett (1978).

The presence of a marine source, very close to our sampling site, is therefore likely responsible for a very fast reloading of the atmosphere with sea-salt particles following a rain event. These considerations give further evidence that the sources of the other elements are not local. Their concentrations are related to a long-range transport of particulate matter from continental sources. Dulac et al. (1987), by using air-mass trajectories, reached the same conclusion.

\subsection{Apparent turn over time of aerosol particles from land-based sources}

The elements subject to a long-range transport from continental source-regions exhibit lower concentrations during the rainy period (Fig. 4). This applies to both pollutant elements and to those associated to mineral aerosol particles derived from soil erosion. Since air-flow patterns do not exhibit seasonal variations (see above), mean seasonal concentration changes can be due to seasonal changes in source strengths and/or to the effect of precipitation scavenging. The first factor is probably not dominant since it is un- likely that elements of different origins would exhibit temporal changes in source strengths of the same magnitude (Fig. 4). Precipitation scavenging appears therefore to be the major cause of the observed pattern.

Moreover, on a shorter time scale, air-mass trajectories at various barometric levels indicate that sharp decreases in concentration observed during a period of precipitation can occur without changes in air-flow patterns (Bergametti, 1987). It seems, therefore, that during the low concentration period (fall and winter), the Mediterranean atmosphere is not completely reloaded between two rain events. Thus, it might be concluded as a first approximation that the mean time interval between two rain events during the rainy season is shorter than the mean travel time of continental aerosols from sourceregions to Corsica. This travel time can be estimated by dividing the duration of the rainy season by the number of days with precipitation. This gives a minimum travel time of about 2 days. The validity of such an estimate has been checked using two other approaches. First, in the case of an interval greater than two days between two consecutive rain events, it is possible to determine the time necessary for the concentrations of any element to reach its pre-rain level. Such cases are observed on the Figs. 1a-d and 

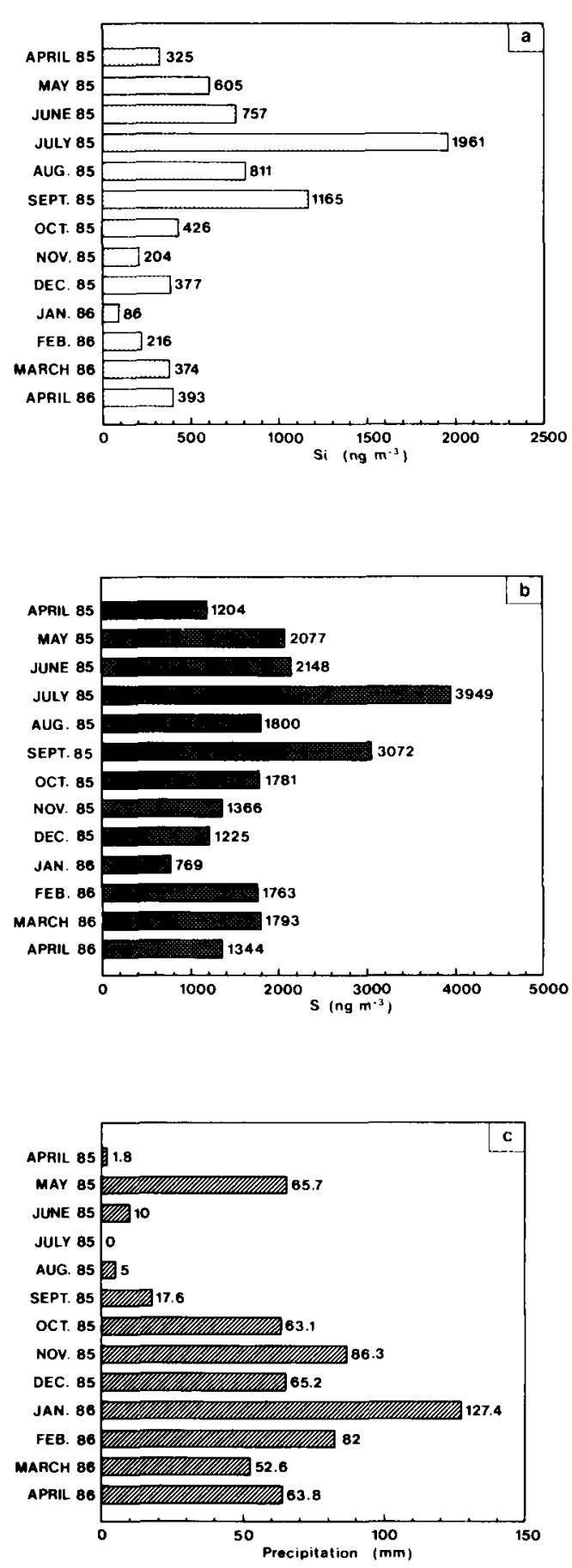

Fig. 3. Monthly geometric means of atmospheric concentrations of (a) $\mathrm{Si}$; (b) $\mathrm{S}$, and monthly mean rainfall (c). indicate that this "reloading" time is generally of the order of $2-3$ days.

Second, taking into account the observed airflow patterns during the rainy season, a travel time of about two days corresponds to a travel distance of about $1000 \mathrm{~km}$. This is approximately the distance between Corsica Island and Spanish or African coasts from which more than $70 \%$ of the sampled air-masses originate (Bergametti, 1987).

\section{Conclusion}

This work was focused on the temporal variability of the atmospheric concentrations in the western Mediterranean Sea. A continuous sampling of particulate matter has been performed over a one year period on a Corsican coastal site.

The strong daily variations of concentrations are mainly due to the Saharan dusts inputs (for the crustal elements) and to the removal of aerosols by precipitation events. Moreover, the precipitations are responsible for the existence of a seasonal cycle for the atmospheric concentrations: during the dry season, the atmospheric concentrations are 2-3 times higher than during the rainy season. $\mathrm{Na}$, which is used as a tracer of sea-salt particles, does not exhibit such a behaviour. This specific behaviour is explained in relation with the local character of the marine source. This allows to conclude that the presence of other elements (of crustal, anthropogenic or mixed origin) results from a long-range transport from continental source-region. A mean travel time of about two days seems to be a good estimate of the duration of the long-range transport between continental source-regions, primarily Spain and north-Africa, and the Corsican atmosphere.

\section{Acknowledgements}

We wish to thank the staff of the signal station of Capo Cavallo for their logitical support during the field experiments in Corsica. We also thank the French Marine Nationale for the free access to the signal station and the French Direction de la Méteorologie Nationale for the use of the meteorological tower at Capo Cavallo. We are

Tellus $41 \mathrm{~B}$ (1989), 3 


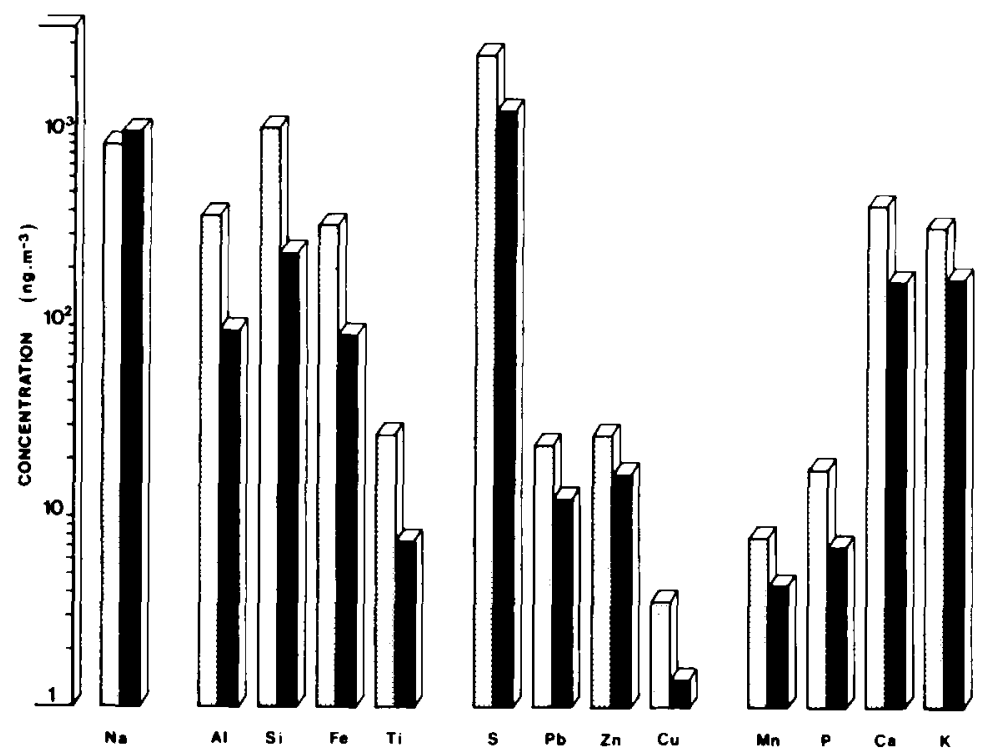

Fig. 4. Geometric means of atmospheric concentrations during the dry and the rainy seasons at Capo Cavallo.

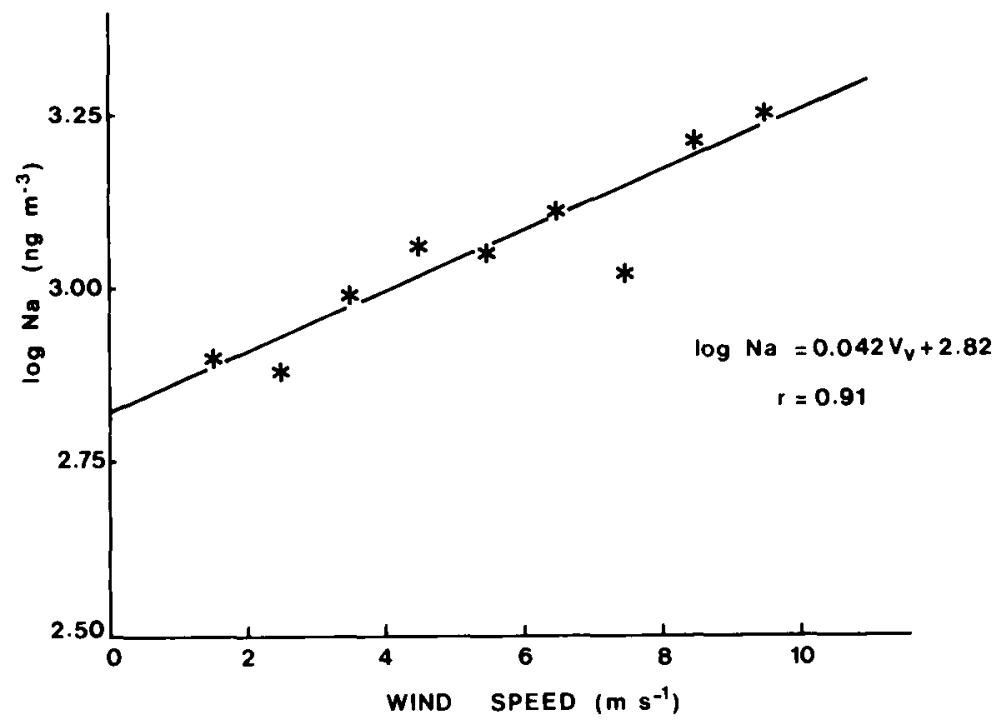

Fig. 5. Atmospheric sodium concentrations versus local wind-speed.

grateful to B. Chatenet, L. Gomes, F. Dulac and $U$. Ezat for their assistance in sampling and analysis. We are particularly grateful to D. Martin, B. Strauss and J. M. Gros who have computed the air-mass trajectories.
This work was supported by the Centre National de la Recherche Scientifique (ATP Aérosols Désertiques, PIREN-TOAE) and the Ministère de l'Environnement (Action Pollution de Fond-Echanges dans l'atmosphère). 


\section{REFERENCES}

Arnold, M., Seghaier, A., Martin, D., Buat-Ménard, P. and Chesselet, R. 1982. Geochemistry of the marine aerosol over the western Mediterranean Sea. In: Comptes Rendus des VI journées d'études sur les pollutions marines en Méditerranée. CIESM Monaco, 27-37 (in French).

Bergametti, G. 1987. Atmospheric inputs to the western Mediterranean Sea: geochemical and meteorological aspects. Ph.D. Thesis. Université Paris 7, 302 pp (in French).

Buat-Ménard, P. 1986. The ocean as a sink for atmospheric particles. In: The rôle of air-sea exchange in geochemical cycling (ed. P. Buat-Ménard). Dordrecht/ Holland: D. Reidel Publ. Comp., 165-181.

Chester, R. Sharples, E. J., Sanders, G. S. and Saydam, A. C. 1984. Saharan dust incursion over the Tyrrhenian Sea. Atmos. Environ. 18, 929-935.

Dulac, F., Buat-Ménard, P., Arnold, M. and Ezat, U. 1987. Atmospheric input of trace metals to the western Mediterranean Sea: 1. Factors controlling the variability of atmospheric concentrations. $J$. Geophys. Res. 92, 8437-8453.

Elichegaray, C., Vié le Sage, R., Grubis, B. and Colin, J. L. 1981. Analysis of atmospheric aerosols by X-ray fluorescence: determination of correcting factors. Analusis 9, 492-497 (in French).
GESAMP (Joint Group of Experts on Scientific Aspects of Marine Pollution) 1985. Atmospheric transport of contaminants into the Mediterranean region. Reports and Studies GESAMP 26. World Meteorological Organisation, $53 \mathrm{pp}$.

Lorenc, A., Rutherford, I. and Larsen, G. 1977. The ECMWF analysis and data assimilation scale analysis of mass and wind field. ECMWF Tech. Rep. 6, Eur. Cent. for Medium-Range Weather Forecasts, Reading, England.

Losno, R., Bergametti, G. and Mouvier, G. 1987. Determination of optima conditions for atmospheric aerosols analyses by X-ray fluorescence. Environ. Tech. Letters 8, 77-87.

Lovett, R. F. 1978. Quantitative measurements of airborne sea-salt in the north Atlantic. Tellus 30, 358363.

Martin, D., Mithieux, C. and Strauss, B. 1987. On the use of the synoptic vertical wind component in a transport trajectory model. Atmos. Environ. 21, 45-52.

Miller, J. M., Martin, D. and Strauss, B. 1987. A comparison of results from two trajectory models used to produce flow climatology to the western Mediterranean. NOAA Tech. Memorandum ERL $A R L-151$, NOAA, Air Resources Laboratory, Silver Spring, Maryland, USA. 